\title{
Keanekaragaman dan Dominansi Jenis Tumbuhan Gulma Pada Perkebunan Kopi di Hutan Wisata Nglimut Kendal Jawa Tengah
}

\author{
Sri Utami ${ }^{1}$, Murningsih ${ }^{1}$, dan Fuad Muhammad ${ }^{1}$ \\ 1Departemen Biologi Fakultas Sains dan Matematika Universitas Diponegoro ; e-mail: utami.biologi@gmail.com
}

\begin{abstract}
ABSTRAK
Gulma merupakan tumbuhan yang kehadirannya tidak diinginkan karena mengganggu dan menurunkan hasil tanamaan budidaya. Tanaman budidaya yang bernilai ekonomi tinggi dan menjadi andalan bagi negara adalah tanaman kopi. Kopi menjadi komuditas yang bisa memberikan kontribusi besar bagi perekonomian di Indonesia. Produktifitas perkebunan kopi salah satunya dipengaruhi oleh tumbuhan gulma yang tumbuh bersama dengan tanaman kopi. Hadirnya tumbuhan gulma di perkebunan kopi akan dapat menurunkan hasil panen. Penelitian ini bertujuan untuk mengetahui keanekaragman dan dominansi jenis gulma yang tumbuh pada perkebunan kopi di hutan wisata Nglimut, Kendal. Teknik penelitian menggunakan purposif sampling dengan menentukan 5 titik sampling secara diagonal. Masing-masing titik sampling diambil 3 plot ukuran 1 x $1 \mathrm{~m}$ untuk kategori rumput/herba dan 3 plot ukuran 5 × $5 \mathrm{~m}$ untuk kategori semak. Data dianalisis secara kuantutatif dengan menghitung kemelimpahan dan Indeks Nilai Penting setiap jenis gulma yang ditemukan. Hasil penelitian didapatkan 15 jenis gulma yang tumbuh di perkebunan kopi. Jenis gulma yang paling banyak adalah dari famili Poaceae ( 4 jenis gulma: Axonopus compressus, Eleusine indica, Oplismenus burmanni dan Panicum repens ) dan Asteraceae (3 jenis gulma: Clidemia hirta, Eleutheranthera rudealis dan Eupatorium odoratum). Jenis gulma yang memiliki kemelimpahan tertinggi dan mendominasi lahan perkebunan kopi adalah Axonopus compressus (INP : 105.475\%) dan Clidemia hirta (INP: 96.53\%). Jenis-jenis gulma tersebut memiliki kemampuan daya kompetisi tinggi dalam memperebutkan sumber daya air, cahaya matahari, unsur hara terhadap pertumbuhan tanaman kopi. Oleh sebab itu jenis gulma tersebut harus mendapatkan penanganan yang serius agar tidak merugikan tanaman kopi dan menurunkan hasil panen. Dengan mengetahui jenis gulma yang dominan dapat untuk menentukan cara pengendalian gulma perkebunan kopi yang tepat dan efisien.
\end{abstract}

Kata kunci : Perkebunan kopi, gulma, dominansi, indeks nilai penting, hutan wisata Nglimut

\begin{abstract}
Weeds are plants whose presence is undesirable because they disturb and reduce the yield of cultivated crops. The cultivated plant which has high economic value is the coffee plant. Coffee is a commodity that can make a major contribution to the economy in Indonesia. One of the reasons for the productivity of coffee plantations is the weeds that grow together with the coffee plants. The presence of weeds in coffee plantations will reduce yields. This study aims to determine the diversity and dominance of the species of weeds that grow in coffee plantations in the Nglimut tourism forest, Kendal. The research technique uses purposive sampling by determining 5 diagonal sampling points. Each sampling point was taken 3 plot sizes of $1 \times 1 \mathrm{~m}$ for the grass / herb category and 3 plots measuring $5 \times 5 \mathrm{~m}$ for the shrub category. Data were analyzed quantitatively by calculating abundance and the Importance Value Index of each species of weed found. The results showed that 15 species of weeds grew in coffee plantations. The most common weed species are from the Poaceae family (4 weed species: Axonopus compressus, Eleusine indica, Oplismenus burmanni and Panicum repens) and Asteraceae (3 weed species: Clidemia hirta, Eleutheranthera rudealis and Eupatorium odoratum). Weed species that have the highest abundance and dominate coffee plantations are Axonopus compressus (IV: 105.475\%) and Clidemia hirta (IV: 96.53\%). This weed species has the ability to compete highly in fighting for water resources, sunlight and nutrients for the growth of coffee plants. Therefore, these weed species must receive serious management so as not to disturb the coffee plant and reduce yields. By knowing the dominant weed species, it can be used to determine the right and efficient way of controlling weeds for coffee plantations.
\end{abstract}

Key words: Coffee plantations, weeds, dominance, important value index; Nglimut tourism forest

Citation: Utami, S., Murningsih . dan Muhammad, F. (2020). Keanekaragaman dan Dominansi Jenis Tumbuhan Gulma Pada perkebunan Kopi di Hutan Wisata Nglimut Kendal Jawa Tengah. Jurnal Ilmu Lingkungan, 18(2),411-416, doi:10.14710/jil.18.2.411-416

\section{Pendahuluan}

Gulma merupakan tumbuhan yang tidak diinginkan karena mengganggu tanaman budidaya dan dapat menurunkan produktifitas. Gulma memiliki sifat sangat kompetitif, mudah berkembang biak dan mudah tumbuh di lingkungan dengan sumber daya yang terbatas sehingga dapat menekan pertumbuhan dan menurunkan hasil tanaman budidaya. 
Menurunnya hasil tanaman budidaya disebabkan adanya kompetisi antara gulma dan tanaman budidaya dalam hal penyerapan hara, air, cahaya matahari dan adanya zat alelopati yang dikeluarkan oleh jenis-jenis gulma tertentu. Gulma yang termasuk Poaceae menghasilkan senyawa alelopati seperti phenolic acids, hydroxamic acids, alkaloid dan quinono. Senyawa alelopati tersebut bisa didapatkan pada bagian akar, polen, biji (Moreiras, et al, 2004). Senyawa alelopati yang dihasilkan tanaman gulma akan dapat menghambat perkecambahan dan pertumbuhan tanaman lain (Wentworth, 2013). Kehadiran gulma di sekitar tanaman kopi tentu juga akan menghambat pertumbuhan tanaman budidaya tersebut (El-Gizawy et al., 2010). Gulma tanaman kopi dapat menurunkan produksi biji 35\% dari 12,5 kw/ ha menjadi $7 \mathrm{kw} /$ ha (Widiyanti, 2013)

Gulma merupakan salah satu masalah yang sering dijumpai dalam budidaya perkebunan.' Hadirnya gulma pada tanaman kopi akan menjadi kompetitor bagi tanaman kopi. Besarnya kerugian atau kehilangan hasil yang diakibatkan oleh gulma berbeda-beda untuk setiap jenis tanaman budidaya, jenis gulma dan faktor-faktor pertumbuhan lainnya. Oleh karena itu, dalam mengendalikan gulma perlu mengetahui jenis gulma dominan, alternatif pengendalian, dampak ekonomi, ekologi dan parasit (Rambe, 2010). Hadirnya gulma di sekitar tanaman kopi akan menunjukkan adanya kelainan morfologi tanaman, antara lain daun menguning, tanaman kerdil atau kurus, cabang-cabang plagiotrop mati, buah berukuran kecil, produksi rendah dan gejala kekurangan unsur hara (Najiyati dan Danarti, 2011). Oleh sebab itu perlu dilakukan pengelolaan pengendalian gulma di sekitar tanaman kopi.

Untuk mendapatkan produksi tanaman budidaya yang tinggi, gulma harus dikendalikan secara benar. Setiap jenis gulma memiliki karakter sendiri dan ini akan menentukan bagaimana cara pengendaliannya. Sebagai contoh, herbisida triklopir (Garlon) dengan dosis 536 g.ba/Ha paling efektif mengendalikan gulma Clidemia hirta (L.) D. Don. dengan angka persentase mortalitas sebesar 97,73 \% (Hafiz et al., 2014).

Tanaman kopi merupakan tanaman unggulan karena akan menyumbang devisa negara yang cukup besar. Produksi kopi di Indonesia cukup tinggi mencapai 600 ribu ton per tahun. Berdasarkan data dari Departemen Pertanian, pada tahun 2008 produksi kopi berkisar 698.106 ton dan pada tahun 2012 produksi kopi turun menjadi 657.138 ton (Departemen Pertanian, 2012). Tanaman kopi merupakan tanaman komoditi unggulan, diharapkan bisa menghasilkan produksi kopi secara maksimal. Salah satu faktor yang menyebabkan produktifitas kopi menurun adalah kehadiran tumbuhan gulma yang tumbuh bersama tanaman kopi. Oleh karena itu, agar diperoleh tanaman kopi produksi tinggi sangat diperlukan tindakan pemeliharaan seperti pemangkasan dan pengendalian gulma (Widiyanti, 2013)
Penelitian ini bertujuan untuk mengetahui keanekaragaman dan tingkat dominansi jenis-jenis tumbuhan gulma yang tumbuh pada lahan perkebunan kopi di hutan wisata Nglimut Kendal. Perbedaan penelitian ini dengan yang lainnya adalah dalam penelitian sebelumnya belum banyak mengungkap karakteristik jenis gulma yang memiliki tingkat dominansi yang tinggi. Jenis-jenis gulma yang memiliki dominansi yang tinggi akan sangat merugikan dan menurunkan produksi tanaman kopi. Seberapa besar penurunan produksi kopi sebagai akibat kompetisi dengan tumbuhan gulma perlu dilakukan penelitian lebih lanjut. Penelitian ini difokuskan pada jenis-jenis gulma apa saja yang tumbuh bersama dengan tanaman kopi. Dengan mengetahui jenis-jenis gulma yang dominan diharapkan bisa digunakan sebagai dasar dalam pengendalian gulma pada perkebunan kopi.

\section{Metode Penelitian}

Penelitian ini dilakukan bulan Juli 2019 pada saat musim kemarau. Lokasi penelitian pada perkebunan kopi di hutan wisata Ngimut Kendal Jawa Tengah. Teknik pengambilan sampel dengan menngunakan purposive sampling dengan menentukan 5 titik sampling secara diagonal. Setiap titik sampling dilakukan pengukuran 3 kali untuk gulma lapisan semak dengan menggunakan plot ukuran $5 \mathrm{~m}$ x $5 \mathrm{~m}$, dan 3 kali untuk lapisan rumput/herba dengan menggunakan plot ukuran $1 \mathrm{~m} \times 1 \mathrm{~m}$. Setiap jenis gulma yang ditemukan dicatat dan dihitung jumlah individunya. Jenis gulma yang belum tahu namanya difoto dan diambil sampelnya untuk dibuat herbaruim. Identifikasi jenis gulma dilakukan di laboratorium Ekologi dan Biosistemnatik Departement Biologi Fakultas Sains dan Matematika Universitas Diponegoro. Variabel yang diamati adalah jumlah individu, frekuensi kehadiran dan luas cover/penutupan setiap jenis gulma yang ditemukan. Data dianalisis dengan menghitung indeks kemelimpahan dan indeks nilai penting (INP) setiap jenisnya. Indeks nilai penting digunakan untuk mengetahui tingkat dominansi jenis tumbuhan gulma di suatu area perkebunan.

Dilakukan pengukuran faktor lingkungan yang meliputi: ketinggan tempat, suhgu udara, kelembaban udara, $\mathrm{pH}$ tanah dan kandungan bahan organik tanah.

Indeks Nilai Penting (INP) dihitung berdasarkan rumus (Soerianegara \& Indrawan, 2005) :

\section{Indeks Nilai penting (INP) $=\mathrm{KR}+\mathrm{FR}+\mathrm{DR}$}

Kerapatan $(\mathrm{K})=$ Jumlah individu

Luas petak pengamatan

Kerapatan relatif $(\mathrm{KR})=\underline{\text { Kerapatan satu jenis }} \times 100 \%$ Kerapatan seluruh jenis

Dominansi (D) = Luas basal area suatu jenis Luas petak pengamatan 
Dominansi relatif $(D R)=\frac{\text { Dominasi suatu jenis } \times 100 \%}{\text { Dominasi seluruh jenis }}$

Frekuensi $(\mathrm{F})=$ Jumlah petak penemuan suatu jenis Jumlah seluruh petak pengamatan

Frekuensi relatif $(F R)=\frac{\text { Frekuensi suatu jenis } \times 100 \%}{\text { Frekuensi seluruh jenis }}$

\section{Indeks Kemelimpahan dan Keanekaragaman} Jenis

Indeks kemelimpahan didasarkan atas indeks Simpson dengan rumus (Fachrul, 2007):

$\mathrm{Di}=\mathrm{ni} / \mathrm{N} \times 100 \%$

Keterangan : Di = Indeks kemelimpahan jenis ke-I

$\mathrm{ni}=$ Jumlah individu suatu jenis

$\mathrm{N}=$ Jumlah total seluruh individu seluruh jenis

\section{Hasil dan Pembahasan}

Dari hasil pengamatan gulma yang tumbuh pada perkebunan kopi di Ngimut Kendal cukup banyak baik jenis maupun jumlah individunya. Secara morfologi tanaman kopi belum terlihat mengalami gangguan atau kerusakan. Kelainan tumbuhan kopi yang diakibatkan hadirnya gulma disekitarnya tidak terlihat jelas seperti misalnya kelainan tanaman kopi yang disebabkan oleh hama dan penyakit ataupun jamur. .

Berdasarkan hasil penelitian yang telah dilakukan pada perkebunan kopi di hutan wisata Nglimut Kendal didapatkan 15 jumlah jenis gulma dan jenis yang paling banyak adalah dari famili Poaceae ( 4 jenis: Axonopus compressus, Eleusine indica, Oplismenus burmanni and Panicum repens) dan famili Asteracea (3 jenis: Clidemia hirta, Eleutheranthera rudealis and Eupatorium odoratum). Hal ini bisa dilihat pada Gambar 1. Hasil ini sama dengan hasil yang didapatkan pada perkebunan kopi rakyat di Malang, dimana jenis gulma yang mendominasi adalah dari famili Poaceae dan Asteraceae (Tampubolon et al., 2019). Penelitian yang lain juga didapatkan bahwa gulma perkebunan kopi yang paling banyak adalah dari famili Poaceae, yang diikui oleh famili Asteraceae, Cyperaceae, and Euphorbiaceae (Tjitrosoedirdjo 2005). Kesamaan jenis gulma dari famili Poaceae dan Asteraceae, disebabkan karena kesamaan habitat yaitu samasama di lahan perkebunan kopi. Selain itu juga jenis tumbuhan dari famili Poaceae dan Asteraceae memiliki sifat yang mudah tumbuh, produksi bijinya banyak dan daya dispersalnya sangat baik sehingga bisa ditemukan di berbagai lahan, baik lahan basah maupun lahan kering.

Namun demikian faktor lingkungan juga akan sangat berpengaruh terhadap kemelimpahan dan dominansi jenis gulma. Sebagai contoh, pada musim kemarau biji-biji gulma yang tidak tahan terhadap kekeringan tidak akan tumbuh dan mengalami dormansi, tetapi begitu ada air saat musim penghujan tiba maka biji-biji gulma tersebut akan tumbuh sangat cepat dan akan mendominasi lahan tersebut.

Poaceae merupakan takson tumbuhan yang memiliki jumlah jenis banyak. Famili ini mempunyai sekitar 500 marga dan 3000 jenis, bersifat kosmopolit, tersebar di berbagai habitat dengan perkembangbiakan yang cepat dan mudah baik secara generatif maupun vegetatif (Moreiras, et al, 2004). Anggota dari famili Poaceae mampu tumbuh pada lahan kering maupun lahan basah. hampir dapat tumbuh dan hidup diseluruh daerah terbuka maupun terlindung baik di daerah triopis maupun sub tropis (Tjitrosoepomo, 2010).

Tumbuhan famili Poaceae selain memiliki sifat yang mudah tumbuh dan dapat mendominasi suatu daerah, juga beberapa jenis gulma dari famili Poaceae bersifat invasif. Dalam penelitian ini adalah jenis Axonopus compressus dan Eleusine indica. Tumbuhan invasif merupakan tumbuhan yang mengintroduksi ke ekosistem lain dan akan menimbulkan kerugian secara ekonomi atau kerusakan lingkungan. Tumbuhan invasif tumbuh dengan cepat dan akan menekan pertumbuhan tanaman yang lainnya (Lowe et al., 2000).

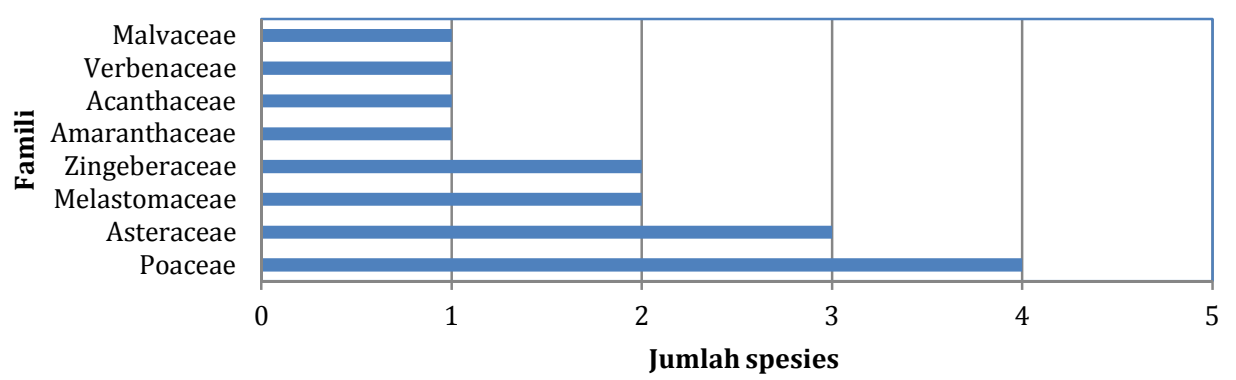

Gambar 1. Jumlah spesies setiap famili tumbuhan gulma pada perkebunan kopi di Nglimut Kendal

Demikian juga dengan takson famili Asteraceae yang memiliki anggota jenis tumbuhan yang banyak. Asteraceae memiliki keanekaragaman tinggi sekitar 25.000 jenis. Biji yang dihasilkan dari tumbuhan famili Asteraceae sangat banyak dan mudah tumbuh di berbagai habitat (Moreiras, et al, 2004). Famili Asteraceae disebarkan melalui biji yang memiliki papus, sehingga bisa diterbangkan oleh angin dengan jarak yang sangat jauh (Wentwoth, 2013). Gulma dari famili Asteraceae juga banyak yang bersifat invasif, dalam penelitian ini termasuk Clidemia hirta dan Eupatorium odoratum. Oleh karena itu jenis-jenis tersebut ditemukan dalam jumlah banyak. 
Hasil identifikasi jenis gulma yang dilakukan pada perkebunan kopi di hutan wista Nglimut, didapatkan 6 jenis tumbuhan gulma kategori rumput/herba dan 9 jenis tumbuhan gulma kategori semak (Tabel 1 dan Tabel 2). Ke 15 jenis gulma tersebut termasuk ke dalam 8 famili yang berbeda.

Tabel 1. Dominansi jenis gulma lapisan rumput/herba pada perkebunan kopi hutan wisata di Nglimut

\begin{tabular}{llllccc}
\hline $\mathbf{N o}$ & \multicolumn{1}{c}{ Spesies } & Nama lokal & Famili & $\mathbf{N i}$ & Di (\%) & INP (\%) \\
\hline $\mathbf{1}$ & Alternanthera philloxeroides & - & Amaranthaceae & 33 & 24,26 & 35,37 \\
\hline $\mathbf{2}$ & Axonopus compressus & Pahitan & Poaceae & 83 & 61,03 & 105,47 \\
\hline $\mathbf{3}$ & Eleusine indica & Lulangan & Poaceae & 3 & 2,21 & 13,32 \\
\hline $\mathbf{4}$ & Oplismenus burmanni & - & Poaceae & 1 & 0,74 & 11,85 \\
$\mathbf{5}$ & Lepidagathis javanica & - & Achantaceae & 1 & 0,74 & 11,85 \\
\hline $\mathbf{6}$ & Panicum repens & Balungan & Poaceae & 15 & 11,03 & 13,32 \\
\hline & Total individu & & & $\mathbf{1 3 6}$ & & \\
\hline & Total jenis & & & $\mathbf{6}$ & \\
\hline
\end{tabular}

Pada Tabel 1 terlihat bahwa gulma Axonopus compressus merupakan gulma yang memiliki kemelimpahan yang paling tinggi (61.06\%) dengan jumlah individu paling banyak (83/plot). Jenis gulma Axonopus compressus juga memiliki INP yang paling tinggi yaitu sebesar 105, 47 \%. Dengan nilai INP yang tinggi ini menunjukkan bahwa jenis gulma ini yang paling mendominasi perkebunan kopi di hutan wisata Nglimut Kendal. Ternyata jenis gulma Axonopus compressus ini juga merupakan jenis yang mendominasi lahan agroforesty jati (Suhartono dan Winara, 2018). Hal ini disebabkan karena Axonopus compressus merupakan gulma yang mudah tumbuh, sangat adaptif serta tahan terhadap kondisi lingkungan yang kurang menguntungkan, sehingga jenis gulma ini dapat dijumpai tumbuh mana-mana.

Axonopus compressus termasuk gulma tahuanan, berkembang biak secara vegetatif dengan stolon dan generatif dengan biji. Gulma Axonopus compressus tumbuh baik di daerah yang kering, agak lembab tapi tidak basah, biasanya tumbuh di lahan perkebunan karet, kelapa sawit, dan juga di pinggir jalan. Gulma Axonopus compressus dapat tumbuh di daerah tropis dan sub tropis. (Sriyani et al, 2014).

Gulma Axonopus compressus termasuk dalam famili Poaceae. Poaceae merupakan famili tumbuhan yang paling besar dan penyebarannya sangat luas. Famili Poaceae disebar luaskan baik secara generatif dan reproduksi vegetatif. Mereka bisa tumbuh melalui biji dan rhizomenya (Wahyuni et al., 2015). Selain itu, Poaceae dilaporkan menghasilkan sentawa alelopatik (Moreiras et al.. 2004), dan bisa menghambat perkecambahan dan pertumbuhan tanaman di sekitarnya (Wentwoth, 2013).

Axonopus compressus juga termasuk tumbuhan bersifat invasif yang berasal dari Amerika tropis (Lowe et al., 2000). Sebagai tumbuhan invasif yang mendominasi lahan perkebunan kopi, Axonopus compressus kehadirannya perlu mendapatkan penanganan yang serius. Pertumbuhan dan perkembangbiakannya yang cepat akan menekan tanaman budidaya dan akan merusak struktur tanah sehingga akan mengganggu pertumbuhan tanaman kopi dan menurunkan hasil panen. Kehadiran spesies tumbuhan invasif ini juga merupakan penghalang serius bagi upaya konservasi dengan dampak yang ditimbulkan (Srivastava et al. 2014).

Penanganan khusus gulma yang tumbuh pada kebun kopi di Nglimut masih kurang, selama ini gulma yang tumbuh hanya dibiarkan. Kemungkinan karena belum menyadari bagaimana tumbuhan gulma yang tumbuh bersama dengan tanaman kopi bisa menurunkan hasil panen kopi. Oleh karena itu, penelitian ini penting untuk dilanjutkan untuk bisa mengetahui seberapa besar kerugian yang ditimbulkan oleh gulma di lahan perkebunan kopi.

Tabel 2. Dominansi jenis gulma lapisan kategori semak pada perkebunan kopi hutan wisata di Nglimut

\begin{tabular}{llllccc}
\hline $\mathbf{N o}$ & \multicolumn{1}{c}{ Spesies } & Nama lokal & Famili & Ni & Di (\%) & INP (\%) \\
\hline $\mathbf{1}$ & Bidens pilosa & Ajeran & Asreraceae & 1 & 2,22 & 10,1 \\
\hline $\mathbf{2}$ & Clidemia hirta & Harendong & Melastomaceae & 18 & 40,0 & 96,53 \\
\hline $\mathbf{3}$ & Costus pictus & - & Zingeberaceae & 1 & 2,22 & 10,38 \\
\hline $\mathbf{4}$ & Curcuma domestica & - & Zingeberaceae & 1 & 2,22 & 12,41 \\
\hline $\mathbf{5}$ & Eleutheranthera rudealis & - & Asteraceae & 5 & 11,11 & 30,97 \\
\hline $\mathbf{6}$ & Eupatorium odoratum & Kirinyu & Asteraceae & 9 & 20,0 & 72,44 \\
\hline $\mathbf{7}$ & Melastoma affine & Senggani & Melastomaceae & 3 & 6,67 & 17,62 \\
\hline $\mathbf{8}$ & Stachytarpheta indica & Jarong & Verbenaceae & 6 & 13,13 & 39,13 \\
\hline $\mathbf{9}$ & Urena lobata & Pulutan & Malvaceae & 1 & 2,22 & 10,38 \\
\hline & Total individu & & & $\mathbf{4 5}$ & & \\
\hline & Total jenis & & & $\mathbf{9}$ & & \\
\hline
\end{tabular}

Dari tabel 2 dapat dilihat bahwa jenis gulma yang ditemukan paling banyak gulma dari suku Asteraceae. Gulma tumbuhan famili Asteraceae merupakan gulma tahunan yang mudah tersebar dengan jumlah populasi yang banyak dan mendominasi lahan (Sukamto, 2007). Pada penelitian ini jenis yang memiliki jumlah individu paling banyak adalah Clidemia hirta (18 individu/plot) yang termasuk dalam famili Melastomaceae dan juga memiliki kemelimpahan tertinggi (40.0\%). Selain itu jenis tersebut juga memiliki indeks nilai penting paling tinggi $(96,43 \%)$. Indeks nilai penting (INP) merupaka 
parameter kuantitatif yang menunjukkan tingkat dominansi (penguasaan) suatu jenis gulma di lahan tersebut (Soeranegara dan Indrawan, 2005). Hal ini meunjukkan bahwa jenis Cliemia hirta merupakan jenis tumbuhan yang mendominasi pada lahan perkebunan kopi.

Clidemia hirta juga mendominasi atau memiliki nilai INP terbesar di kawasan Hutan Kenali, Jambi dengan nilai 141,83\% (Susanti et al., 2013). Jenis ini juga ditemukan mendominasi lahan karet dan juga kelapa sawit (Wahyuni et al., 2015). Selain itu Clidemia hirta juga ditemukan paling melimpah dengan jumlah individu paling banyak dan mendominasi karena memiliki indeks nilai penting tertimggi di kawasan hutan raya Jambi (Nursanti dan Adriadi, 2018).

Clidemia hirta merupakan gulma yang memiliki pertumbuhan yang sangat cepat, tumbuh di berbagai habitat dari lingkungan kering sampai basah, toleran terhadap perubahan lingkungan, tahan kekeringan sampai 6 bulan walaupun tunasnya sudah mati (Binggeli, 2005). Hadirnya tumbuhan Clidemia hirta, perlu mendapatkan perhatian yang serius karena tumbuhan ini termasuk tumbuhan invasif yang tidak hanya menyerang lahan pertanian dan perkebunan, namun juga menginvasi kawasan hutan (Peters, 2001). Tumbuhan yang bersifat invansif akan tumbuh subur dan mendominasi tempat yang baru sehingga menyebabkan kepunahan spesies asli (Lowe et al., 2000).

Tabel 3. Faktor lingkungan pada perkebunan kopi hutan wisata di Nglimut

\begin{tabular}{llc}
\hline No & \multicolumn{1}{c}{ Faktor lingkungan } & Hasil \\
\hline $\mathbf{1}$ & Ketinggian tempat (mdpl) & $750-800$ \\
\hline $\mathbf{2}$ & pH tanah & $6,5-7,0$ \\
\hline $\mathbf{3}$ & Intensitas cahaya (lux) & $120-130$ \\
\hline $\mathbf{4}$ & Kelembaban udara $(\%)$ & $57-70$ \\
\hline $\mathbf{5}$ & Suhu udara $\left({ }^{\circ} \mathrm{C}\right)$ & $22-24$ \\
\hline $\mathbf{6}$ & Bahan organik tanah & 32,96 \\
\hline
\end{tabular}

Dari hasil pengukuran faktor lingkungan, terlihat bahwa lingkungan sangat mendukung untuk pertumbuhan tanaman perkebunan kopi. Secara visual memang belum nampak terlihat gangguan atau kelainan tanaman kopi yang diakibatkan oleh tanaman gulma yang tumbuh bersama dengan tanaman kopi. Hanya tanaman kopi terlihat agak kerdil dengan cabang-cabang yang menjalar. Gangguan atau kerusakan tanaman kopi tidak seperti gangguan yang disebabkan oleh penyakit lain misalnya serangan hama dan jamur akan menimbulkan gejala kelainan morfologi tanaman kopi. Namun adanya kompetisi dalam memperebutkan sumber daya alam yang tersedia ini akan menurunkan hasil panen tanaman kopi.

Lokasi penelitian berada pada ketinggian 50-800 mdpl. Menurut Permentan (2014) budidaya tanaman kopi yang paling baik berada pada ketinggian 1000 mdpl, dengan $\mathrm{pH}$ tanah berkisar 6,5. Dengan demikian faktor lingkungan di perkebunan kopi Nglimut masih memenuhi syarat untuk pertumbuhan tanaman kopi. 415
Hasil pengukuran suhu udara berkisar antara 22$24{ }^{\circ} \mathrm{C}$. Hasil ini sedikit diatas suhu tara-rata untuk pertumbuhan kopi, namun belum menimbulkan gangguan. Rata-rata suhu optimum untuk kopi adalah berkisar 18-21 ${ }^{\circ} \mathrm{C}$ (DaMatta dan Ramalho, 2006). Suhu di atas $23^{\circ} \mathrm{C}$, dapat mempercepat pengembangan dan pematangan buah sehingga menurunkan kualitas (Camargo, 2010). Jika suhu udara mencapai $30 \stackrel{\circ}{\circ} \mathrm{C}$ dapat mengakibatkan pertumbuhan tanaman tertekan dan menimbulkan kelainan seperti menguningnya daun dan pertumbuhan tumor pada pangkal batang (DaMatta dan Ramalho, 2006).

\section{Kesimpulan}

Jenis gulma yang banyak ditemukan pada perkebunan kopi di hutan wisata Nglimut Kendal adalah 15 jenis. Jumlah jenis paling banyak dari famili Poaceae (4 jenis gulma: Clidemia hirta, Eleutheranthera rudealis dan Eupatorium odoratum) dan Asteraceae (3 jenis gulma: hirta, Eleutheranthera rudealis dan Eupatorium odoratum). Jenis gulma yang memiliki kemelimpahan tertinggi dan mendominasi pada perkebunan kopi di hutan wisata Nglimut adalah Axonopuspus compressus (INP: 105,47) dan Clidemia hirta (INP: 96.3). Penelitian ini perlu dilanjutkan untuk mengetahui seberapa besar pengaruh dominansi gulma terhadap produksi kopi.

\section{UCAPAN TERIMA KASIH}

Dengan selesainya penelitian ini penulis mengucapkan banyak terima kasih kepada Pak Joko Suryanto, Pak Sumbowo yang telah membantu menyiapkan alat-dan perlengkapan penelitian. Kepada para mahasiswa Teguh Tri Hatmoko, Evananda dan Tria Waroka yang telah banyak membantu dalam pengambilan data di lapangan.

\section{DAFTAR PUSTAKA}

Binggali, P. 2005. Crop Protection Compendium-Clidemia hirta (L.) D.Don. http://home.vicnet.net.au/ invasive/downloads/fer alherald3.pdf. Diunduh 10 Juni 2020

DaMatta, F. M and J. D. C. Ramalho. 2006. Impacts of drought and temperature stress on coffee physiology and production: a review. Brazilian J. Plant. Physiol. 18: 5581.

Departemen Pertanian. 2012. Produksi Kopi Menurut Propinsi di Indonesia, 2008-2012. www.deptan.go.id. Diakses pada tanggal 3 Juli 2020.

El-Gizawy, N.Kh.B., A.M. Fadlallah, A.M. Hassanein and I.E. Soliman. 2010. Estimation of the Critical Period for Weed Control in Soybean (Glycine max L.) as Influenced by Plant Den-sity. Agypt. J of. Agricultural Rese-arch Center. 2 (4): 7-9.

Fachrul, M.F. 2007. Metode Sampling Bioekologi. Bumi Aksara. Jakarta.

Hafiz, A. Purba E, Sengli B dan Damanik J. 2014. Efikasi Beberapa Herbisida Secara Tunggal dan Campuran Terhadap Clidemia hirta (L.) D. Don. Di Perkebunan Kelapa Sawit. Jurnal Agroekoteknologi, 2 (4) : 15781583 
Lowe S, Browne M, Boudjelas S. dan De Poorter M. 2000. 100 of the World's Worst Invasive Alien Spesies A selection from the Global Invansive Species Database.

Moreiras AMS, Weiss OA, Roger MJR. 2004. Allelopathic evidence in Poaceae. The Botanical Review 69 (3): 300-319.

Najiyati S. dan Danarti. 2011. Kopi Budidaya dan Penanganan Lepas Panen. Edisi Revisi. Penebar Swadaya, Jakarta

Nursanti dan Adriadi A. 2018. Keanekaragaman Tumbuhan Invasif Di Kawasan Taman Hutan Raya Sultan Sultan Thaha Saifudin Jambi. Media Konservasi 23 (1) : 85-91

Peraturan Menteri Pertanian Nomor 49/Permentan/OT.140/4/2014. Pedoman Teknis Budidaya Kopi yang Baik

Peters H.A. 2001. Clidemia hirta Invasion at the Pasoh Forest Reserve : An unexpeted Plant Invasion in an undisturbed tropical forest. Bioptropica, 33 (1) : 60-68

Rambe, T.D, L. Pane, P. Sudharto dan Caliman. 2010. Pengelolaan Gulma Pada Perkebunan Kelapa Sawit di PT. Smart Tbk. Jakarta.

Soerianegara I. \& Indrawan A. (2005). Ekosistem Hutan Indonesia. Bogor: Laboratorium Ekologi Hutan. Fakultas Kehutanan, IPB.

Suhartono, S dan Winara, A. 2018. Keragaman dan Potensi Pemanfaatan Jenis Gulma Pada Agroforesty Jati (Tectona grandis L.) dan Jalawure (Tacca leontopetaloides (L.) Kuntz) Jurnal Penelitian Hutan dan Konservasi Hutan, 15 (2): 66-77
Sukamto. 2007. Babadotan (Ageratum conyzoides) Tanaman Multi Fungsi yang Menjadi Inang Potensial Virus Tanaman. Warta Puslitbangbun, 13 (3) : 2-5

Srivastava SA, Dvidedi RP, Shukla. 2014. Invasive Alien Spesies of Teresterial Vegetation of North Eastren. International Journal of Forestry Research. 4 (1): 1-9.

Tampubolon E.P, Setiawan A dan Sudiarso. 2019. Analisis Vegetasi di Perkebunan Kopi Rakyat dan PTPN XII dengan Naungan yang Berbeda. Jurnal Produksi Tanaman, 7 (1) : 81-89

Tjitrosoedirdjo, S. 2005. Inventory of the invasive alien plant species in Indonesia. BIOTROPIA 25:60-73

Tjitrosoepomo, G. 2010. Spermatophyta. Gadjah Mada Press Yogyakarta

Wahyuni, I., Sulistyorini dan Tjitrosoedirdjo S.2015. Inventory of Invasive Plant Species at Bukit Duabelas and the Vicinity, Jambi,Sumatra. Proceeding Papers of Internationalon Biosciences (IcoBio): 52-61

Wahyuni, R, Solfiyeni, Chairul. 2015. Analisis Vegetasi Spesies Tumbuhan Asing Invasif di Kawasan Cagar Alam Lembah Harau. Prosiding Seminar Bioeti 3;19. Padang Indonsia. Padang (ID): Jurusan Biologi Universitas Andalas

Wentworth J. 2013. Postnote: Invasive Alien Plant Species. http://www.parliament.uk/documents/ POST/postpn439_invasive-alien-plants-peciesreferences.pdf.

Widiyanti, T. 2013. Kondisi Kebun Sumber Benih Kopi (Coffea sp) di Kebun Kalisat Jampit Bondowoso. Balai Besar Perbenihan dan Proteksi Tanaman Perkebun2an. Surabaya. 